\title{
Electrochemical and Spectroscopic Properties of Technetium in Fused Alkali Metal Chlorides
}

\author{
V. A. Volkovich ${ }^{\mathrm{a}}$, B. D. Vasin ${ }^{\mathrm{a}}$, and T. R. Griffiths ${ }^{\mathrm{b}}$ \\ ${ }^{a}$ Department of Rare Metals and Nanomaterials, Ural State Technical University-UPI, \\ Ekaterinburg, 620002, Russia \\ ${ }^{\mathrm{b}}$ Redston Trevor Consulting, Ltd., Leeds, LS17 8RF, UK
}

The behavior of metallic technetium in chloride melts was studied for the first time. The experiments were conducted in $\mathrm{NaCl}-2 \mathrm{CsCl}$ eutectic melt at $550{ }^{\circ} \mathrm{C}$ using high temperature electronic absorption spectroscopy, cyclic voltammetry and chronopotentiometry. The anodic dissolution of Tc results in the formation of a mixture of Tc(IV) and a lower oxidation state species. Cyclic voltammograms of technetium-containing melts show two cathodic and two associated anodic peaks. One pair is around $-0.35 \mathrm{~V}$ vs. $\mathrm{Ag} / \mathrm{AgCl}$ reference electrode and is associated with the deposition of Tc metal.

\section{Introduction}

High temperature alkali metal chloride-based melts are prospective media for nonaqueous pyrochemical reprocessing of spent nuclear fuels. Technetium is an important fission product and is formed in light-water reactors with an abundance ratio of just below 0.06 per fission (1). The concentration of this fission product does not change much upon cooling and even after 10 years its content in the spent fuel (after burn-up of $33 \mathrm{GW} \cdot \mathrm{d} / \mathrm{t}$ ) is $835 \mathrm{ppm}$. In the irradiated oxide fuel technetium is present in elemental form as a constituent of so-called "white inclusions" - alloys of Mo, Tc, Ru, Rh, Pd and Ag (1-3). There are currently two developed pyrochemical processes for treating spent nuclear fuels in fused chlorides, one (ANL, Argonne, USA) uses molten 3LiCl-2KCl eutectic, and the other (RIAR, Dimitrovgrad, Russia) based on $\mathrm{NaCl}-\mathrm{KCl}$ or $\mathrm{NaCl}-2 \mathrm{CsCl}$ melt, but the behavior of technetium in molten salts, particularly its electrochemical and physico-chemical properties, remain essentially unknown.

Rhenium is often employed as a surrogate for radioactive technetium but obtaining reliable data for technetium obviously requires studying the element itself. Previously we studied the reactions of technetium dioxide with chlorine and hydrogen chloride in a range of molten salts (4). We employed both high temperature electronic absorption spectroscopy and X-ray absorption spectroscopy, and reported the electronic absorption spectra of $\mathrm{Tc}(\mathrm{IV})$ ions in chloride melts (4). The reaction of $\mathrm{TcO}_{2}$ with $\mathrm{HCl}$ led to the formation of soluble $\mathrm{TcCl}_{6}{ }^{2-}$ species, whilst using $\mathrm{Cl}_{2}$ resulted in the conversion of $\mathrm{TcO}_{2}$ into pertechnetate species (soluble in the melt) and volatile oxychlorides. It appears that the only published open literature study involving technetium metal and molten salts was a Raman spectroscopy investigation of the reaction of Tc with molten lithium perchlorate (5). Technetium dissolves in $\mathrm{LiClO}_{4}$ at around $250-300{ }^{\circ} \mathrm{C}$ yielding the pertechnetate species. 
In the present work the behavior of metallic technetium was investigated in $\mathrm{NaCl}-$ $2 \mathrm{CsCl}$ eutectic based melts at $550{ }^{\circ} \mathrm{C}$. The work involved the anodic dissolution of elemental technetium using in situ electronic absorption spectroscopy measurements, and also spectroscopic, electrochemical (cyclic voltammetry and chronopotentiometry) and spectroelectrochemical measurements of technetium-containing melts.

\section{Experimental}

The experimental techniques have been described previously (4). Electronic absorption spectra were measured using a custom built set-up based on the fiber optic spectrometers AvaSpec-2048-2 and AvaSpec-NIR256-1.7 (Avantes) and an optical furnace INSTRON SFL TF1726. The electrochemical measurements were performed employing an Autolab PGSTAT302N potentiostat/galvanostat. Electrode potentials were measured vs. $\mathrm{Ag} / \mathrm{AgCl}(1 \mathrm{~mol} \%$ in $\mathrm{NaCl}-2 \mathrm{CsCl})$ reference electrode and all the potential values below are given relative to this reference electrode unless stated otherwise. All experiments were performed under an argon atmosphere, commercial grade argon having been additionally purified by passing through heated zirconium turnings.

For anodic dissolution a rectangular piece of technetium foil (approx. $6 \times 37 \mathrm{~mm}^{2}$ ) was mechanically attached to a molybdenum wire that acted as a current conductor. The connection point between molybdenum and technetium was always at least $2 \mathrm{~cm}$ above the melt surface. A molybdenum wire dipped in $\mathrm{NaCl}-2 \mathrm{CsCl}$ melt containing $\mathrm{PbCl}_{2}$, held in a silica tube separated from the bulk of the melt by a diaphragm, acted as the cathode. For electrochemical and spectroelectrochemical measurements the optical cell $(1 \mathrm{~cm}$ pathlength) also contained a glassy carbon working electrode and an $\mathrm{Ag} / \mathrm{AgCl}$ reference electrode.

\section{Results and discussion}

Anodic dissolution of technetium

The corrosion potential of metallic technetium was measured after dipping the technetium working electrode in $\mathrm{NaCl}-2 \mathrm{CsCl}$ eutectic melt. At $550{ }^{\circ} \mathrm{C}$ it was around $0.50-0.57 \mathrm{~V}$. Anodic dissolution was conducted at constant current. The anodic current density varied from 0.010 to $0.048 \mathrm{~A} / \mathrm{cm}^{2}$. As the anodic dissolution progressed the color of the melt became yellow and then yellowish-brown and red-brown as the concentration of technetium species in the melt increased. An example of the electronic absorption spectra recorded during the anodic dissolution is given in Figure 1. In the spectra recorded in the beginning of the dissolution there is a shoulder around $420 \mathrm{~nm}$ that disappeared as the concentration of technetium ions in the melt increased. The final spectra contain the low energy edge of the charge transfer band and a well pronounced maximum around $700 \mathrm{~nm}$. Apart from the absorbance increase the spectral profile did not change during anodic dissolution. The spectra recorded were resolved into individual overlapping bands (employing a PeakFit software) and examples of the results obtained are shown in Figure 2. The quenched melt was yellow and an example of the diffuse reflectance spectrum of the solidified melt at room temperature containing the products of the anodic dissolution of technetium is shown in Figure 3. The maxima in the spectrum are at ca. 300, 360 and $700 \mathrm{~nm}$. 


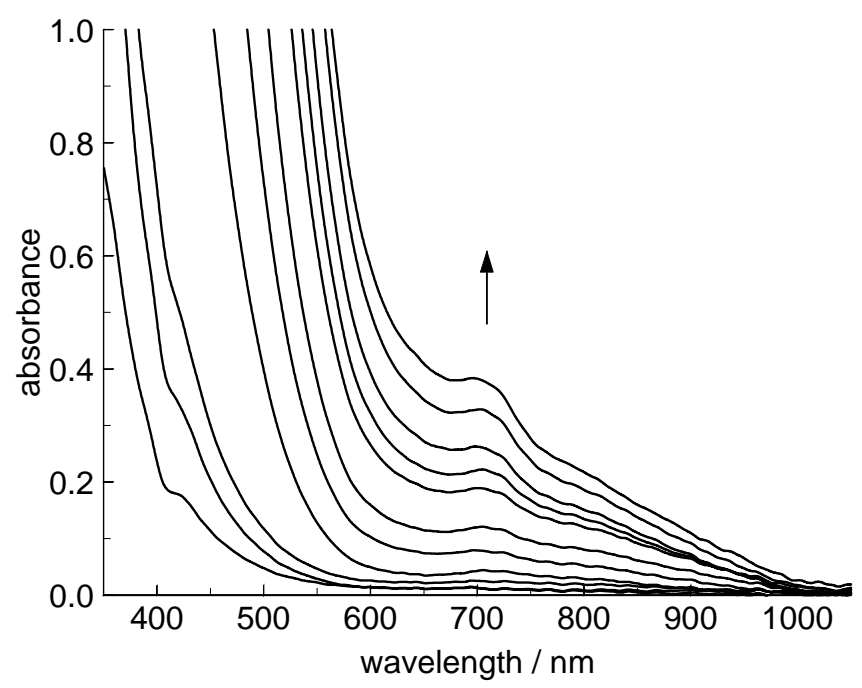

Figure 1. Electronic absorption spectra recorded during anodic dissolution of technetium in $\mathrm{NaCl}-2 \mathrm{CsCl}$ melt at $550{ }^{\circ} \mathrm{C}$ and with anodic current density of $0.018 \mathrm{~A} / \mathrm{cm}^{2}$. Experiment terminated after $40 \mathrm{~min}$. Arrow shows the direction of the spectral change.
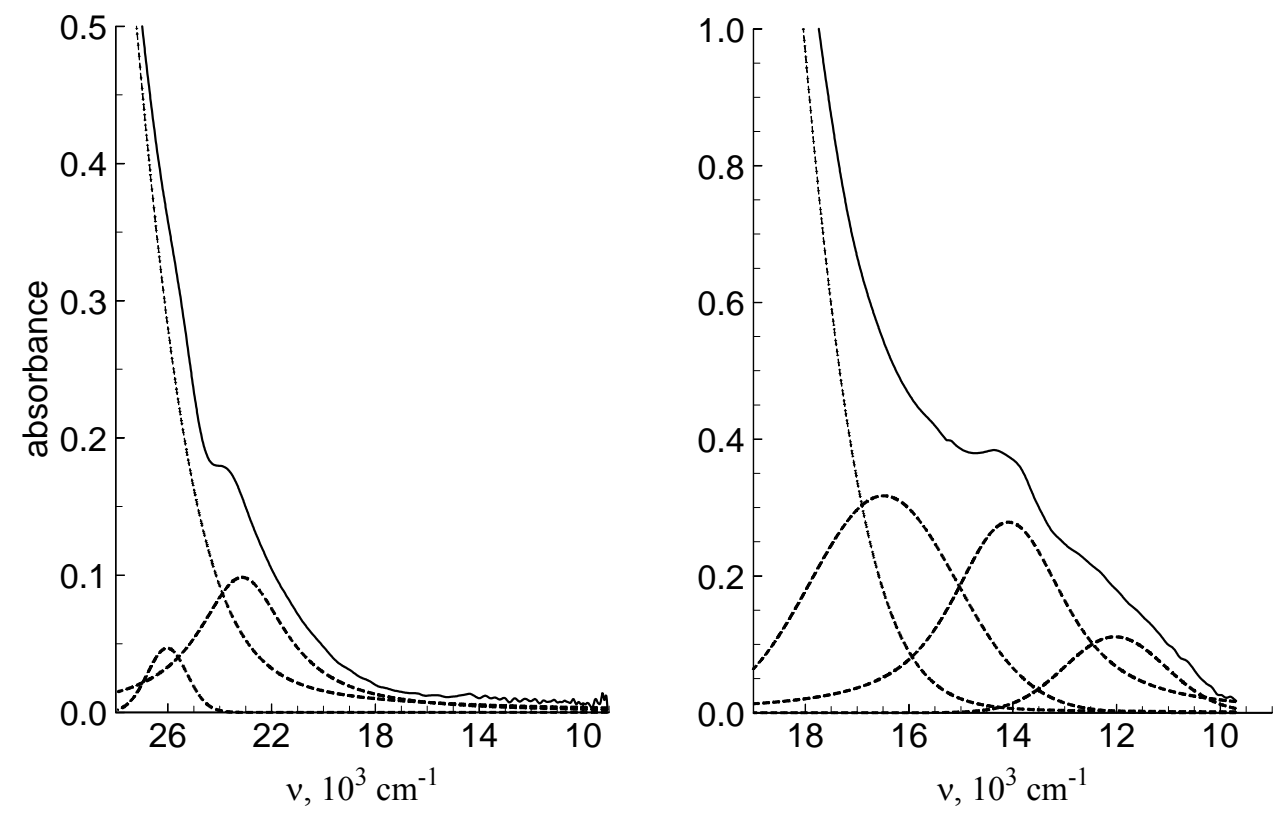

Figure 2. Resolution of the electronic absorption spectra recorded during the anodic dissolution of $\mathrm{Tc}$ in $\mathrm{NaCl}-2 \mathrm{CsCl}$ melt at $550{ }^{\circ} \mathrm{C}$. Time of dissolution: $5 \mathrm{~min}$ (left) and 40 min (right).

The results of the anodic dissolution experiments are summarized in the Table I. With only one exception the number of electrons (n) was between three and four for the reaction,

$$
\mathrm{Tc}-\mathrm{n} \mathrm{e} \rightarrow \mathrm{Tc}^{\mathrm{n}+}
$$

calculated from the anode weight decrease and the amount of the electricity passed. There was no dependence of the value of $n$ on the anodic current density. In one case (at the highest current density used) the value of $n$ was 3.0. Thus at present we can conclude 
that technetium normally dissolves forming a mixture of Tc(IV) and a lower oxidation state species, for which the oxidation state could be 3 or lower. If two lower oxidation species are formed then they could have oxidation states 3 and 2. Various chloro dimers involving technetium have been reported of proposed and cannot be ruled out at this time. Species with oxidation states higher than 4, well known for its congener manganese, do not appear to be formed in our system.

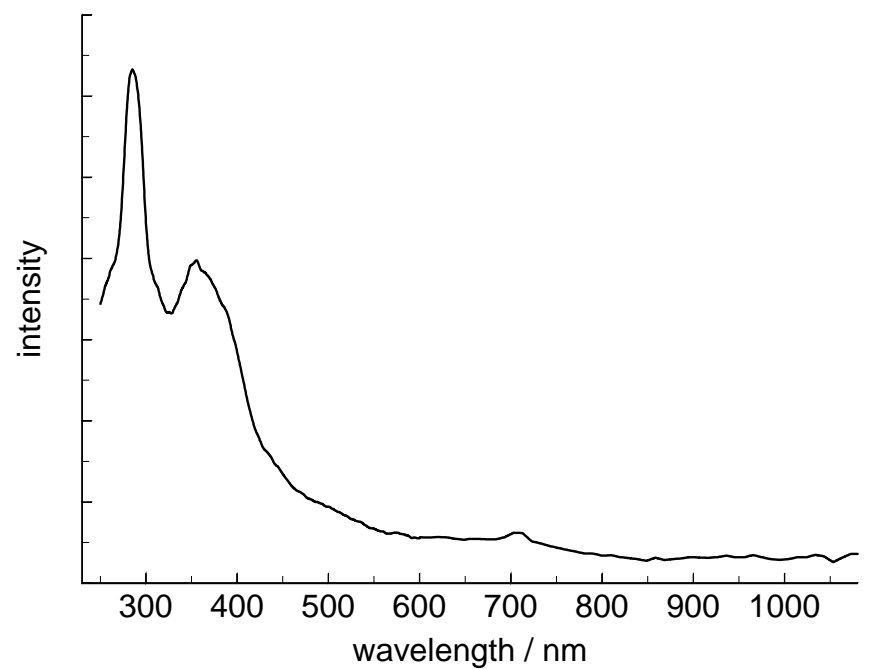

Figure 3. Diffuse reflectance spectrum of quenched $\mathrm{NaCl}-2 \mathrm{CsCl}$ melt containing the products of the anodic dissolution of metallic technetium.

TABLE I. Anodic dissolution of technetium in $\mathrm{NaCl}-2 \mathrm{CsCl}$ melt at $550{ }^{\circ} \mathrm{C}$.

\begin{tabular}{cccc}
\hline $\begin{array}{c}\text { Anodic current density, } \\
\mathbf{A} / \mathbf{c m}^{\mathbf{2}}\end{array}$ & $\begin{array}{c}\text { Amount of electricity passed, } \\
\mathbf{C}\end{array}$ & $\begin{array}{c}\text { Anode weight decrease, } \\
\mathbf{g}\end{array}$ & $\mathbf{n}$ \\
\hline 0.010 & 40.8 & 0.0120 & 3.49 \\
0.018 & 48.0 & 0.0129 & 3.82 \\
0.018 & 24.0 & 0.0068 & 3.62 \\
0.048 & 24.0 & 0.0082 & 3.00 \\
\hline
\end{tabular}

There are several studies of technetium chloro-species formed in hydrochloric acid solutions and the following species with the oxidation state of four and below were characterized or have been proposed: $\mathrm{TcCl}_{6}{ }^{2-}, \mathrm{Tc}_{2} \mathrm{Cl}_{8}{ }^{2-}$ and $\mathrm{Tc}_{2} \mathrm{Cl}_{8}{ }^{3-}$ (6-9). In our previous study we recorded the electronic absorption spectrum of $\mathrm{TcCl}_{6}{ }^{2-}$ in chloride melts; the coordination and the oxidation state of technetium were confirmed by the results of X-ray absorption spectroscopy measurements (4). A comparison of the absorption spectra of $\mathrm{NaCl}-2 \mathrm{CsCl}$ based melts containing $\mathrm{TcCl}_{6}{ }^{2-}$ species (prepared by reacting $\mathrm{TcO}_{2}$ with $\mathrm{HCl}$ ) and the products of anodic dissolution of Tc metal is made in Figure 4. The absorption bands in the spectrum of $\mathrm{TcCl}_{6}{ }^{2-}$ species (spectrum 2 in Figure 4) agree with the reported data and the band around $700 \mathrm{~nm}$ can be attributed to the ${ }^{4} \mathrm{~A}_{2 \mathrm{~g}} \rightarrow{ }^{2} \mathrm{~T}_{2 \mathrm{~g}}$ transition, while the broad band above $950 \mathrm{~nm}$ is due to ${ }^{4} \mathrm{~A}_{2 \mathrm{~g}} \rightarrow{ }^{2} \mathrm{E}_{\mathrm{g}}$ and ${ }^{4} \mathrm{~A}_{2 \mathrm{~g}} \rightarrow{ }^{2} \mathrm{~T}_{1 \mathrm{~g}}$ transitions $(6,7)$. The spectrum of the melt containing the products of $\mathrm{Tc}$ anodic dissolution (spectrum 1 in Figure 4) also exhibits an absorption band around 700 $\mathrm{nm}$ which overlaps other bands around 650-850 nm (cf. Figure 2). Although the results of the anodic dissolution experiments presented in Table I suggest that there should be some $\mathrm{Tc}(\mathrm{IV})$ species present, there is surprisingly very low absorption above $900 \mathrm{~nm}$ and 
measuring the spectra further in the near-IR region to $1700 \mathrm{~nm}$ did not show appreciable absorption in that region.

The absorption spectrum of another possible candidate, $\mathrm{Tc}_{2} \mathrm{Cl}_{8}{ }^{3-}$, also has a peak around 640-660 nm (7). Unfortunately no information concerning the absorption of $\mathrm{Tc}_{2} \mathrm{Cl}_{8}{ }^{3-}$ species above $700 \mathrm{~nm}$ could be found. So far it is difficult to unambiguously interpret the spectra of the melts containing the products of the anodic dissolution of technetium and thus additional electrochemical studies were performed in an attempt to clarify the situation.

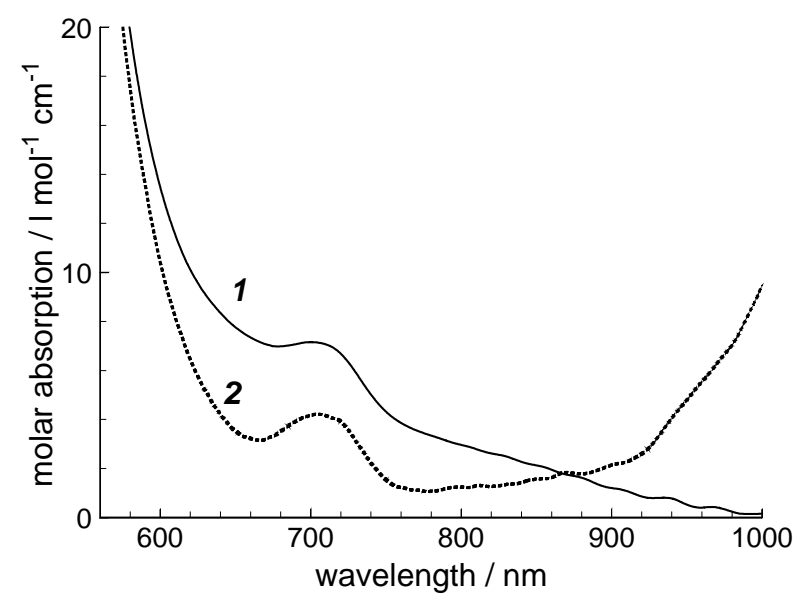

Figure 4. Absorption spectra of $\mathrm{NaCl}-\mathrm{CsCl}$ eutectic melts containing technetium species introduced by: 1, anodic dissolution of $\mathrm{Tc}$ metal; 2, reacting $\mathrm{TcO}_{2}$ with $\mathrm{HCl}$. Temperature $550{ }^{\circ} \mathrm{C}$.

\section{Electrochemical studies of technetium-containing melts}

A series of electrochemical experiments was conducted using the melts prepared by anodic dissolution of metallic technetium. The zero-current potential of technetium in $\mathrm{NaCl}-2 \mathrm{CsCl}$ melt containing $\mathrm{Tc}$ chloro-ions is around 0.3-0.4 V vs. $\mathrm{Ag} / \mathrm{AgCl}$ reference

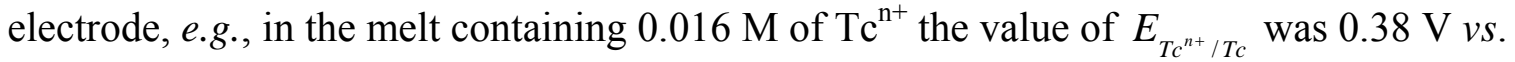
$\mathrm{Ag} / \mathrm{AgCl}$ (or $c a$. $-0.9 \mathrm{~V}$ vs. $\mathrm{Cl}^{-} / \mathrm{Cl}_{2}$ ) reference electrode. A glassy carbon electrode in the same melt gave a potential value of $0.57 \mathrm{~V}$ vs. $\mathrm{Ag} / \mathrm{AgCl}$. Examples of the cyclic voltammograms measured in $\mathrm{NaCl}-\mathrm{CsCl}-\mathrm{TcCl}_{\mathrm{n}}$ melt on a glassy carbon working electrode are shown in Figure 5. There is one cathodic and one corresponding anodic peak. The position of the cathodic peak shifts towards negative potentials as the scan rate increases while the position of the anodic peak remains essentially unaffected. Beginning the scans in the anodic direction (Figure 6) showed the absence of the anodic peak in the first scan, only after passing through the cathodic peak the corresponding anodic peak appeared (right plot in Figure 6). Chronopotentiograms recorded in the melts containing the products of anodic dissolution of technetium have a distinct inflection at $c a .0 .4 \mathrm{~V}$ (Figure 7), confirming that an electrochemical reaction is taking place around this potential.

Shifting the cathodic limit in the negative direction, Figure 8, resulted in the appearance of the second cathodic and associated anodic peak ( $c_{2}$ and $a_{2}$ in Figure 8). 
The shapes of these peaks are typical for the deposition and dissolution of a solid product. Shifting the anodic limit in the positive direction led to the evolution of chlorine.

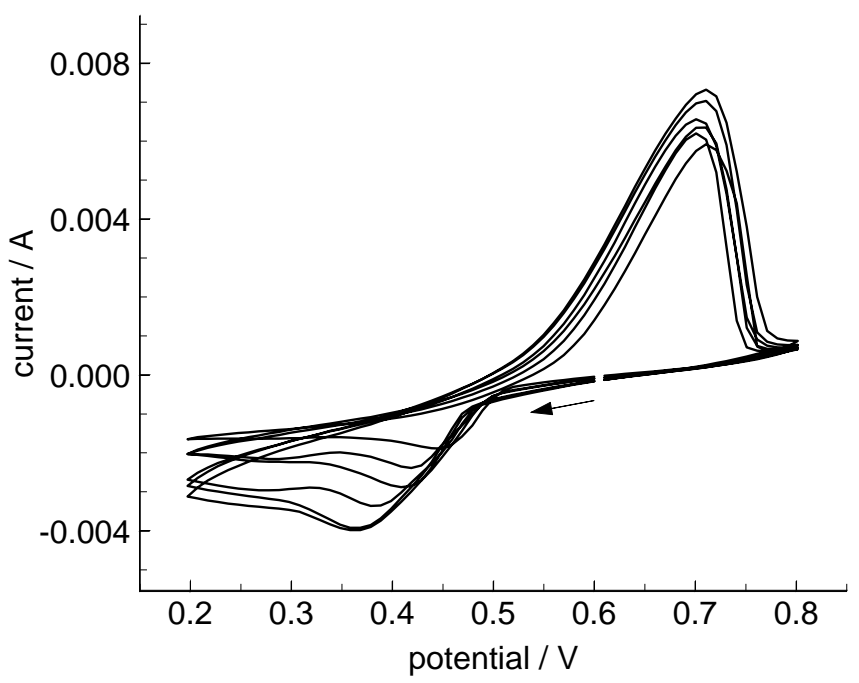

Figure 5. Cyclic voltammograms of technetium species in a $\mathrm{NaCl}-2 \mathrm{CsCl}$ melt at $550{ }^{\circ} \mathrm{C}$ measured using a glassy carbon working electrode. Scan rates 10, 20, 30, 50, 70 and $80 \mathrm{mV} / \mathrm{sec}$. Tc concentration ca. $0.026 \mathrm{~mol} / \mathrm{dm}^{3}$. Arrow shows beginning and direction of the scans.
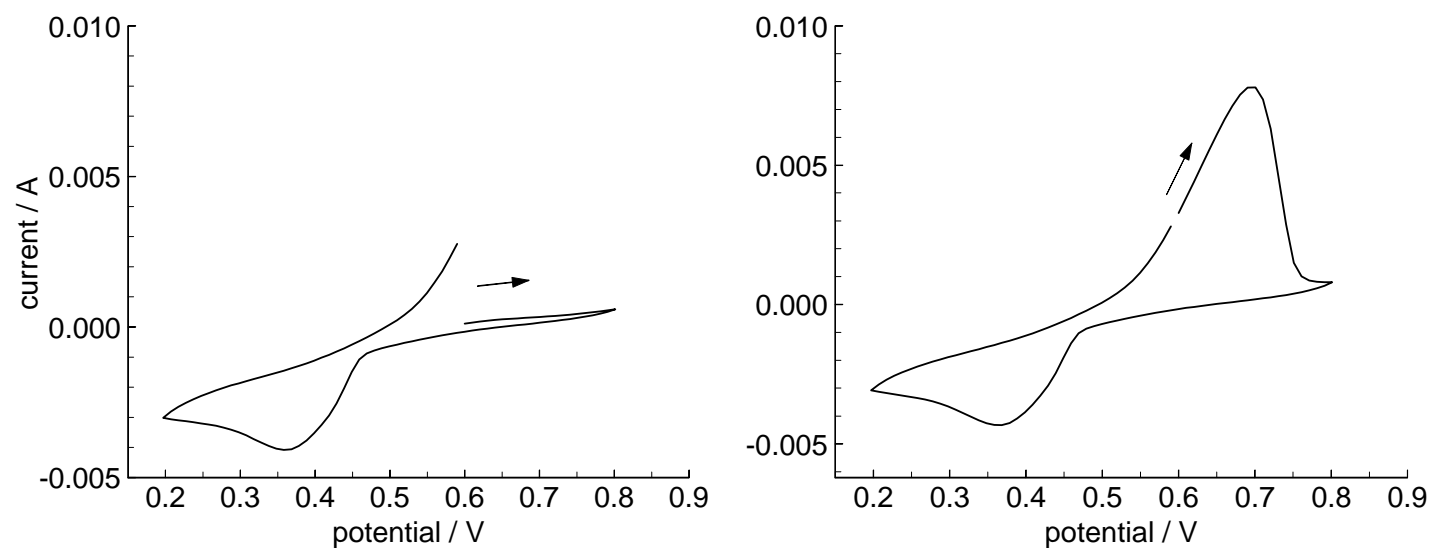

Figure 6. Cyclic voltammograms of technetium species in a $\mathrm{NaCl}-2 \mathrm{CsCl}$ melt at $550{ }^{\circ} \mathrm{C}$ measured in the anodic direction and showing the first (left) and the second (right) scans. Scan rate $100 \mathrm{mV} / \mathrm{sec}$. Tc concentration ca. $0.026 \mathrm{~mol} / \mathrm{dm}^{3}$. Arrows show beginning and direction of the scans. Glassy carbon working electrode.

Thus the cyclic voltammograms recorded in technetium containing melts, Figure 8, exhibit two cathodic waves at potentials around $0.5 \mathrm{~V}\left(\mathrm{c}_{1}\right)$ and $-0.4 \mathrm{~V}\left(\mathrm{c}_{2}\right)$ vs. silver chloride reference electrode and two corresponding anodic waves at $c a$. $-0.3 \mathrm{~V}\left(\mathrm{a}_{2}\right)$ and $0.6 \mathrm{~V}\left(\mathrm{a}_{1}\right)$. These waves are attributed to the following reversible reactions:

$$
\begin{aligned}
& \mathrm{Tc}^{4+}+\mathrm{ne}^{-} \rightarrow \mathrm{Tc}^{(4-n)^{+}} \\
& \mathrm{Tc}^{(4-\mathrm{n})^{+}}+(4-\mathrm{n}) \mathrm{e}^{-} \rightarrow \mathrm{Tc}^{0}
\end{aligned}
$$

Cyclic voltammograms recorded in the $\mathrm{NaCl}-2 \mathrm{CsCl}$ melt containing the products of anodic dissolution of technetium on a technetium working electrode, Figure 9, contained 
the cathodic and anodic waves corresponding to the deposition and dissolution of Tc metal, reaction [3]. The anodic limit was determined by the reaction [2]. Only when the potential during the anodic scan was shifted to $0.75 \mathrm{~V}$ a cathodic peak around $0.4 \mathrm{~V}$ appeared (right graph in Figure 9).

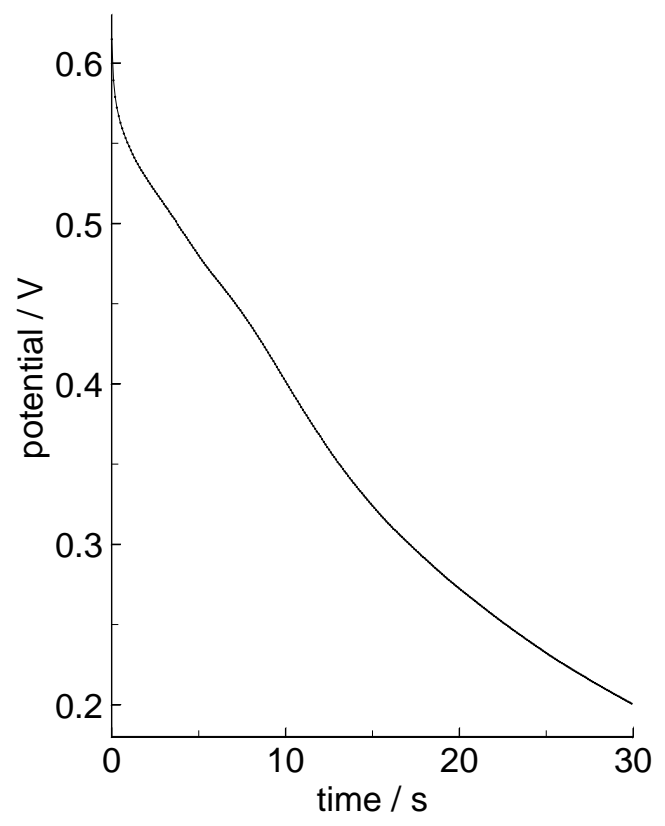

Figure 7. Chronopotentiogram of $\mathrm{NaCl}-2 \mathrm{CsCl}$ melt containing the products of anodic dissolution of technetium at $550{ }^{\circ} \mathrm{C}$. Current value $0.75 \mathrm{~mA}$, glassy carbon working electrode.

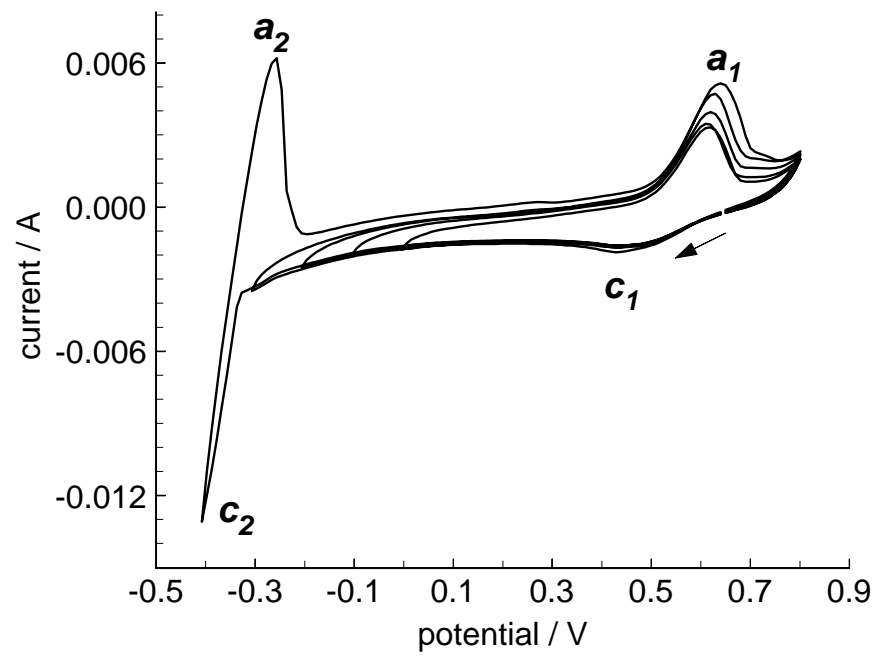

Figure 8. Cyclic voltammograms of technetium in a $\mathrm{NaCl}-2 \mathrm{CsCl}$ melt at $550{ }^{\circ} \mathrm{C}$ recorded using a glassy carbon working electrode. The cathodic limit was progressively varied from 0 to $-0.4 \mathrm{~V}$. Scan rate $100 \mathrm{mV} / \mathrm{sec}$. Tc concentration $c a .0 .026 \mathrm{~mol} / \mathrm{dm}^{3}$.

The results of these preliminary electrochemical studies show that technetium species having two different oxidation states are present in chloride melts in contact with metallic technetium. The results of the spectroscopy measurements and anodic dissolution 
experiments suggest that one of the forms is Tc(IV). The lack of information concerning the behavior and speciation of technetium in molten salts does not allow a definite conclusion concerning the nature of the second (low oxidation state) species. Technetium(III), in the form of $\mathrm{TcCl}_{6}{ }^{3-}$ or $\mathrm{Tc}_{2} \mathrm{Cl}_{8}{ }^{2-}$, or a mixed oxidation state $\mathrm{Tc}_{2} \mathrm{Cl}_{8}{ }^{3-}$ are the possible candidates.
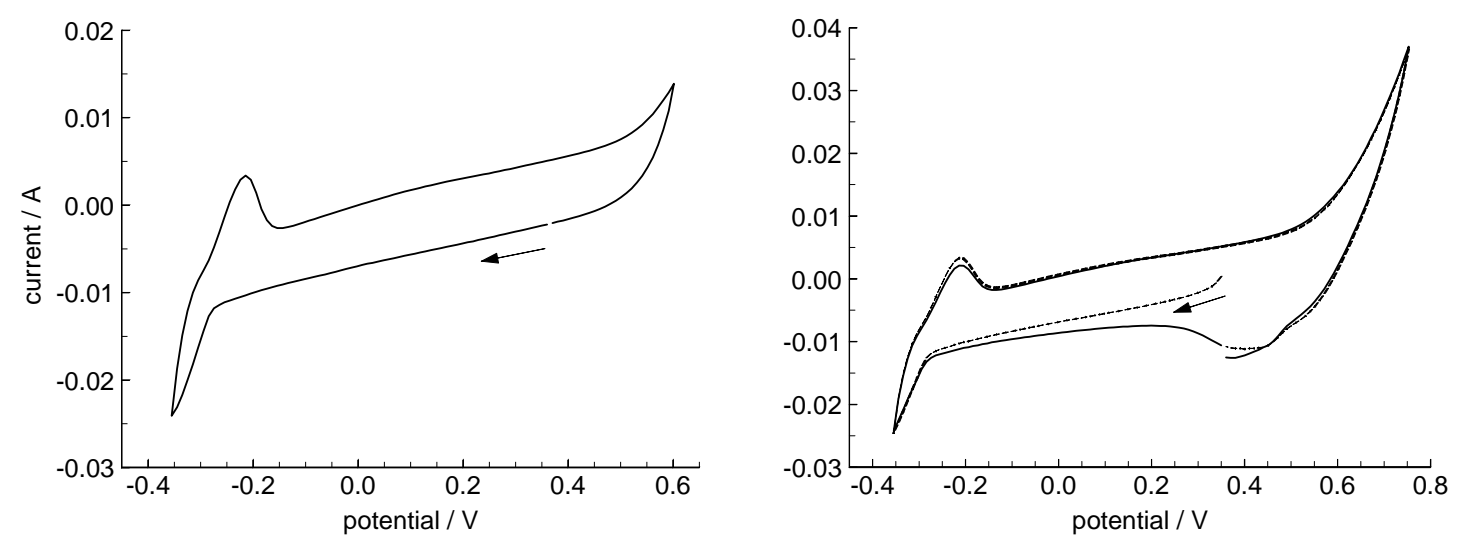

Figure 9. Cyclic voltammograms of technetium species in a $\mathrm{NaCl}-2 \mathrm{CsCl}$ melt at $550{ }^{\circ} \mathrm{C}$ measured using a technetium metal working electrode. Anodic potential limit $0.6 \mathrm{~V}$ (left) and $0.75 \mathrm{~V}$ (right). Tc concentration ca. $0.017 \mathrm{~mol} / \mathrm{dm}^{3}$. Scan rate $100 \mathrm{mV} / \mathrm{sec}$. Arrows show beginning and direction of the scans. First and second scans are shown in the right plot.

Technetium containing melts are sensitive to the oxygen present in the atmosphere. Allowing small amounts of oxygen contamination in the atmosphere above the melt changed the profile of cyclic voltammograms. An additional anodic peak appeared around $0.75 \mathrm{~V}$ with no corresponding cathodic wave, Figure 10 . There were no visible changes in the electronic absorption spectra or the color of the melts held under the oxygen contaminated atmosphere. IR spectra of the quenched melt samples from a number of experiments carried out in the oxygen contaminated atmosphere exhibited peaks at $c a .902 \mathrm{~cm}^{-1}$. This frequency region is typical for the vibration of Tc-O bonds and it can be concluded that the reaction of oxygen with technetium chloro-species in the melt result in the formation of a technetium oxychloride (10).
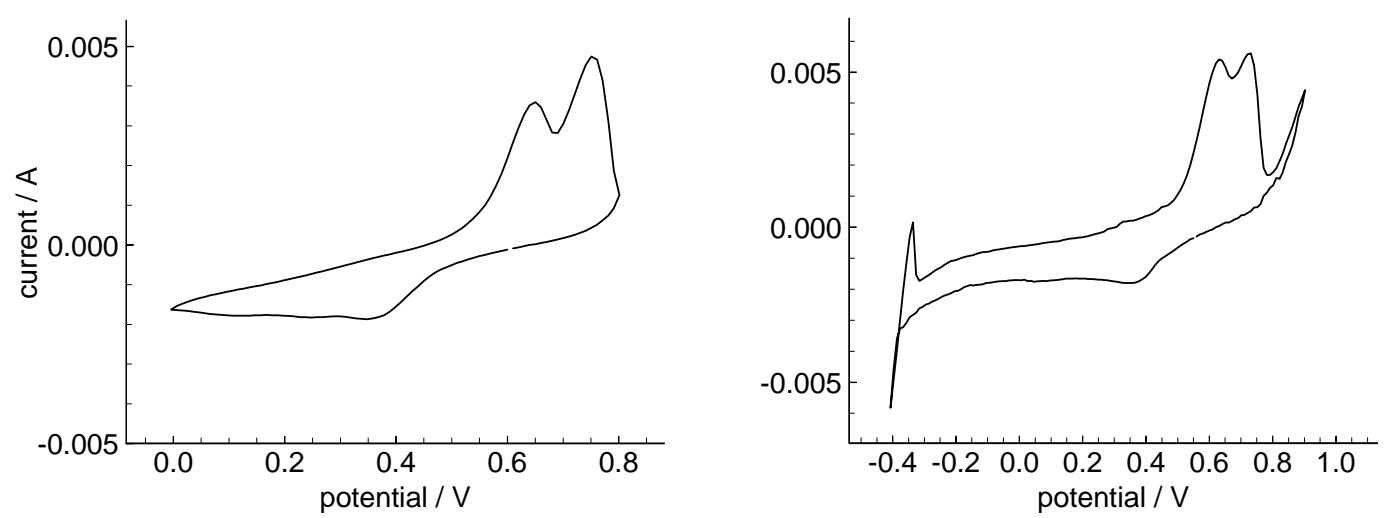

Figure 10. Cyclic voltammograms of technetium in a $\mathrm{NaCl}-2 \mathrm{CsCl}$ melt at $550{ }^{\circ} \mathrm{C}$ in the presence of small amounts of oxygen in the atmosphere above the melt. Glassy carbon working electrode. Tc concentration ca. $0.05 \mathrm{~mol} / \mathrm{dm}^{3}$. 
From the results of electrochemical measurements a very rough estimate of the technetium deposition potential value in $\mathrm{NaCl}-2 \mathrm{CsCl}$ melt at $550{ }^{\circ} \mathrm{C}$ can be obtained. The formal standard potential $E_{T c^{(4-n)+} / T c}^{*}$ would be expected between -0.17 and $0.54 \mathrm{~V}$ vs. $\mathrm{Ag} / \mathrm{AgCl}$ reference electrode (or between -1.45 and $-0.74 \mathrm{~V}$ vs. chlorine reference electrode). Assuming that the low oxidation state technetium species is Tc(III), the Gibbs free energy formation change $\Delta G^{*}$ for $\mathrm{TcCl}_{3}$ in the melt would be expected between -214 and $-420 \mathrm{~kJ} / \mathrm{mol}$. Since $\Delta G$ of formation for liquid $\mathrm{TcCl}_{3}$ at $550{ }^{\circ} \mathrm{C}$ is around $-105 \mathrm{~kJ} / \mathrm{mol}$ then $\Delta G^{*}$ of mixing $\mathrm{TcCl}_{3}$ with molten $\mathrm{NaCl}-2 \mathrm{CsCl}$ eutectic mixture at this temperature is between -109 and $-315 \mathrm{~kJ} / \mathrm{mol}$.

\section{Spectroelectrochemical studies of technetium-containing melts}

To determine the possibility of forming low oxidation state technetium species in the melt a potentiostatic electrolysis was performed in a melt containing the products of anodic dissolution of technetium. The potential was chosen from the results of cyclic voltammetry and set at $0.3 \mathrm{~V}$ vs. $\mathrm{Ag} / \mathrm{AgCl}$ reference electrode. The electronic absorption spectra recorded during the reduction process are shown in Figure 11. The electrolysis was carried out on a glassy carbon working electrode and the potential applied was changed first from $0.3 \mathrm{~V}$ (30 min of electrolysis time), then to $0.2 \mathrm{~V}$ (for $10 \mathrm{~min}$ ) and finally to $0.1 \mathrm{~V}$ (for $10 \mathrm{~min}$ ). The total amount of electricity passed during the cathodic reduction was $7.25 \mathrm{C}$ (compared with $48 \mathrm{C}$ passed during the anodic dissolution of Tc to prepare the starting melt).

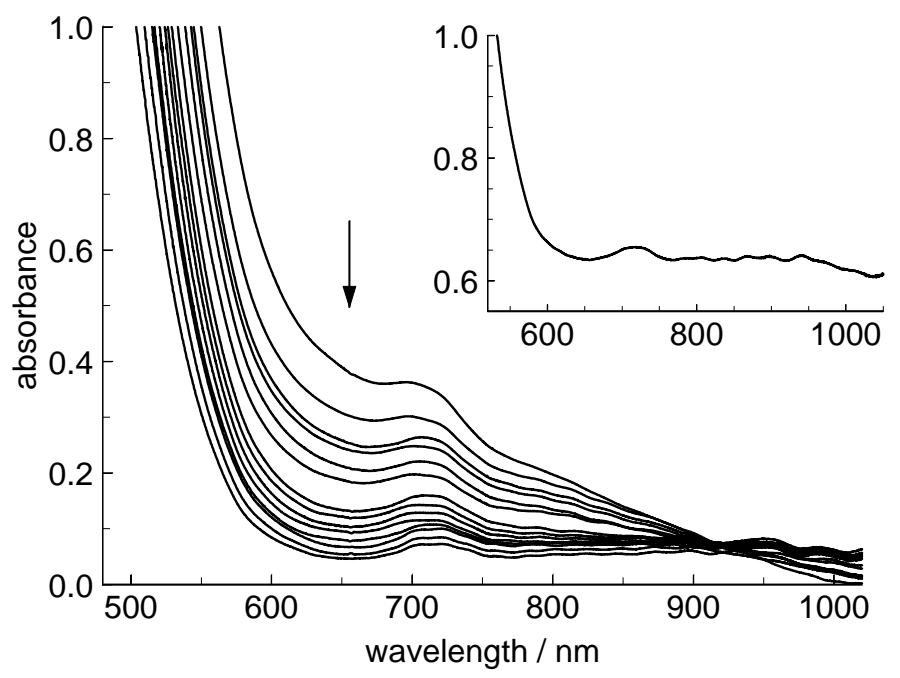

Figure 11. Electronic absorption spectra recorded during potentiostatic reduction of $\mathrm{NaCl}-2 \mathrm{CsCl}$ melt containing the products of anodic dissolution of technetium at $550{ }^{\circ} \mathrm{C}$ (constant background subtracted). Insert shows last spectrum before background subtraction. Reduction potential $0.3 \mathrm{~V}$ (for $30 \mathrm{~min}$ ) followed by $0.2 \mathrm{~V}(10 \mathrm{~min})$. The arrow shows the direction of the spectral change.

During electrolysis the color of the melt changed from dark reddish-brown to light greenish-brown. The background in the spectra was gradually increasing in the entire wavelength region (up to $1700 \mathrm{~nm}$ ) indicating that one or more insoluble species are formed in the bulk of the melt. The spectra presented in Figure 11 have this constant background subtracted. The position of the absorption peak around $720 \mathrm{~nm}$ remained 
unchanged. No additional bands in the spectrum were formed. After completing the experiment some black precipitate was observed in the experimental cell and the surface of the working electrode was plated with a metallic-like radioactive (and thus technetium containing) deposit.

\section{Conclusions}

The behaviour of metallic technetium in alkali chloride based melts was investigated for the first time and the results of the preliminary electrochemical and spectroscopic studies in $\mathrm{NaCl}-2 \mathrm{CsCl}$ eutectic melt at $550{ }^{\circ} \mathrm{C}$ are presented. Anodic dissolution of metallic technetium at anodic current densities between 10 and $48 \mathrm{~mA} / \mathrm{cm}^{2}$ yields a mixture of Tc(IV) and a lower oxidation state, presumably Tc(III), chloro-species. The mixture of these technetium species is present in the melt in the equilibrium with Tc metal. The cyclic voltammograms recorded in technetium containing melts have two cathodic and two corresponding anodic waves at the potentials around 0.5-0.6 V and -(0.3-0.4) V vs. silver chloride reference electrode. The former is attributed to the $\mathrm{Tc}^{4+}+\mathrm{ne}^{-} \rightarrow \mathrm{Tc}^{(4-\mathrm{n})^{+}}$recharge and the latter to the deposition and dissolution of metallic technetium.

\section{References}

1. S. Imoto, J. Nucl. Mater., 140, 19 (1986).

2. H. Kleykamp, J. Nucl. Mater., 131, 221 (1985).

3. J. I. Bramman, R. M. Sharpe, D. Thom and G. Yates, J. Nucl. Mater., 25, 201 (1968).

4. V. A. Volkovich, I. May, J. M. Charnock and B. Lewin, Phys. Chem. Chem. Phys., 4, 5753 (2002).

5. D. Cohen, S. Fried, H. Selig, J. Inorg. Nucl. Chem., 33, 2687 (1971).

6. C. K. Jorgensen and K. Schwochau, Z. Naturforsch., 20a, 65 (1965).

7. S. V. Kryuchkov, A. F. Kuzina and V. I. Spitsyn, Russ. J. Inorg. Chem., 28, 1124 (1983).

8. F. A. Cotton, P. E. Fanwick, L. D. Cage, B Kalbacher and D. S. Martin, J. Am. Chem. Soc., 99, 5642 (1977).

9. F. A. Cotton and E. Pedersen, Inorg. Chem., 14, 383 (1975).

10. K. Nakamoto, Infrared and Raman spectra of inorganic and coordination compounds, p. 138, 141, Wiley Interscience, New York (1986). 